\title{
Global Issues in ESP Classroom: Challenges and Opportunities in Higher Education
}

\author{
Yana Diachkova \\ Department of Foreign Languages of the Faculty of Economics of Taras Shevchenko NationalUniversity of \\ Kyiv, Ukraine \\ Corresponent Authpr: yanadyachkova@i.ua
}

\begin{abstract}
Lilia Sazhko
Department of German Philology of the Institute of Philology of Borys Hrinchenco KyivUniversity, Ukraine

Liudmyla Shevchenko

Department of Foreign Languages of the Faculty of Economics of Taras Shevchenko NationalUniversity of Kyiv, Ukraine

Anastasiia Syzenko

Department of Foreign Languages of the Faculty of Economics of Taras Shevchenko NationalUniversity of Kyiv, Ukraine
\end{abstract}

Received: 11/1/2020 Accepted: 3/1/2021 Published: 3/24/2021

\begin{abstract}
In English for Specific Purposes, one of the challenges is to transform teaching and learning into a process, which focuses on the development of professional skills, enables students to become successful learners of the target language, and makes them more aware of the local and global environments. This paper aims to analyse key challenges that teachers and learners face in the classrooms and suggest a way of integrating global issues into the process of development of professional soft and hard skills. The paper studies the existing ESP literature in terms of presence of global issues, explores the perceptions of global issues among university students in Ukraine, outlines the correlation between professional skills and global competence. The findings suggest that there are numerous advantages of introducing materials based on global issues into the teaching process as it has synergetic effect of fusing professional skills, soft skills and global competence. The paper concludes that this fusion improves the skill set of a future professional and has a positive impact on the quality of higher education in general.

Keywords: English for Specific Purposes, ESP, global education, global issues, professional skills, soft skills, life competences, higher education, classroom challenges, Ukraine

Cite as: Diachkova, Y., Sazhko, L., Shevchenko, L., \& Syzenko,A. (2021). Global Issues in ESPClassroom: Challenges and Opportunities in Higher Education. Arab World English Journal, 12(1)388 -400. DOI: https://dx.doi.org/10.24093/awej/vol12no1.26
\end{abstract}




\section{Introduction}

Since the introduction of global education approach, the focus in a foreign language teaching context has switched to making sure that students not only effectively acquire the foreignlanguage as a means of personal or professional communication, but also gain understanding, skills, and commitment to become truly global citizens and make their contributions to dealing with global problems. It is quite challenging for educators, including foreign language teachers, to transform teaching and learning into a process which focuses both on equipping students to be successful learners of the target language and making them more aware and respectful to their surroundings.

Thus, foreign language classroom is becoming a place where students not only acquire language to communicate effectively in personal and professional settings, but also develop mindset and skills needed for world citizens to be able to contribute to tacking the problems of global scale. This makes it crucial for the future professionals to be engaged in making change happen by means of changing their behaviours (Hogg \& Shah, 2010). This is becoming particularly relevant in the times of recent global pandemic that the students and graduates realise the global setting and their role in bringing about positive change to the world.

According to the Global Situation Report (2020), a significant work has been done in the sphere of global problems resolution due to huge progress in health and poverty reduction in recent decades. At the same time there are still challenges connected with unequal growth, a changing climate, world conflicts etc. The world needs citizens who are able to serve communities under these challenging circumstances, that makes global competence be of a crucial importance for labour market. And education is the key to progress. It is the key to the culture of democracy that encourages effective functioning of democratic laws and institutions. Essential to this is ensuring that "the young develop their global competence and acquire the knowledge, values and capacity to be responsible citizens in modern, diverse, democratic societies" (Council of Europe, 2018, p. 5).

However, transforming teaching and learning into a process that goes beyond equipping students to become successful learners of the target language or proficient speakers may turn intoa challenge for many educators. Rather than focusing solely on the language required for students' professional needs, foreign language teachers are now to develop their students' awareness of the global problems and using language effectively to show more respect and tolerance to their surroundings. Therefore, it is important to identify the role and place of global issues in the ESP classroom and explore opportunities for integrating global issues into the development of skills and competences in the higher education context.

This paper aims to analyse main challenges and suggest ways of integrating global issues into the process of development of professional skills, soft skills, and global competence in the ESP classroom. The premise is that the fusion of professional skills, soft skills, and global competence is likely to improve the employment profile of a future professional and suggests a positive impact of global education approach within ESP classes on learning process and on quality of higher education in general. 


\section{Literature Review}

In the English for Specific Purposes context, global education is a pedagogical approach that sees peace, human rights, development, and the environment as core content areas of educating aglobal citizen and aims to develop learners as professionals and committed citizens of the world. The matter is that it is not demanded in ESP context to implement this approach into the teachingpractice. That makes contemporary ESP teaching stand still in this respect and creates a gap between the requirements of modern labour market and professional competence of highereducation graduates.

Moreover, the view of a language learner in the ESP context is becoming much more complex as well. In his recent publication, Michael Byram considers a language learner from the perspective of three interconnected facets, emphasizing more and more strongly the idea of the language learner as an engaged and responsible citizen:

- a person with an open mind

- a person with the curiosity and courage of the ethnographer

- a person with the engagement and responsibility of the citizen (Byram, 2020, p. 5).

According to the researcher, these facets suggest that learning a language is more than learning a set of skills, it is an opportunity to develop as a person. Therefore, teaching should be designedto offer a learner such an opportunity, to challenge learners' views of the target language, tomake them aware of and reflect on possible stereotypes and prejudices concerning target- language countries and people, etc. According to this very concept, the language learner observes people's practices in a target-language community, interprets narratives and documents, reflects on norms, beliefs and values, and in the process learns something about themselves. That makes the learner more engaged, conscious and responsible for the learning process in itself. Byram's third facet draws on the field of citizenship education - across subjects and including language teaching. In this perspective, the language learner should be seen as an engaged and responsible citizen. And according to the author, "learning a language is an opportunity to develop as a citizen, taking the vantage point of 'the other' to analyze one's own country and people, with a view to changing it for the better" (Byram, 2020, p. 5). That instinctively leads the learner to developing global competence and becoming aware of the global citizenship.

Moreover, English for Specific Purposes is a field of language teaching that enjoys quite a specific nature. This gives educators some room for manoeuvre and allows them to orientatetheir language learners towards global consciousness and awareness. According to Kennedy (2007),

Through its occupational, institutional and subject-specific rigor, ESP potentially offers grounded micro-perspectives on language, power and identity that have, at times, been found lacking in the theoretical adventurism often prevalent in critical texts. Conversely, for ESP, critical theories and pedagogies enhance contextual understanding and potentially expand the linguistic means by which goal-directed ends can be effectively achieved in this context and enhance the possibilities for transformative pedagogies that are invigorated through a fusion of pragmatic and politicized strategies. Such global- national tensions have given rise to contested and competing notions of citizenship in 
ESP settings but also to creative and transformational pedagogies in which second language learners can be oriented towards social justice issues of local, national and international consequence. (p. 310)

Indeed, the responsibilities of foreign language educators are not limited only to teaching vocabulary, grammar, pronunciation, listening, speaking, reading, and writing. Even without realizing that, ESP instructors worldwide already integrate global issues and global educationinto their teaching in a variety of ways involving, for example, content used for input during lessons. However, as educators, our mission is to pay attention to problems occurring globally and consciously prepare our students for active participation in tackling the problems or at least showing sympathy and tolerance to those suffering from these issues. Teachers and learners may not be able to solve the global issues directly, still our understanding and compassion toward the situations and problems are critical in helping to reduce the spread of the issues. According to recent studies, global issues are crucial to be introduced and implemented into language teaching. It has been researched and proved that global learning fosters:

- critical and creative thinking

- self-awareness and open-mindedness towards difference

- understanding of global issues and power relationships, and

- optimism and action for a better world (Hogg \& Shah, 2010).

In Ukraine, challenges associated with teaching ESP mostly stemmed from the fact that most teachers had no or very little practical training in ESP teaching; the legacy of grammar- translation method has led to teaching mostly decontextualized English having no relation to students' professional needs and students' low motivation (Onishchuk \& Andrusiak, 2018). Moreover, another recent study suggests that there is a strong relationship between the use of learning models of the ESP language course and improvement of the experimental group students' critical thinking seen as a combination of such components as affective, argumentative, and reflexive (Karapetian, 2020).

Since this paper aims to explore the existing situation in ESP classrooms in higher education in Ukraine, it should be noted that the country faces several challenges related toglobal education overall. Not unlike in other countries, they touch upon several dimensions: knowledge, skills, attitudes, and action and include:

- Knowledge about world countries and cultures, and about global problems. If our aim is to educate students able to work for a better world, they must know the nature of world problems, their causes, and solutions.

- Development of soft skills which include communication, critical and creative thinking, collaboration, problem-solving, conflict resolution, decision making, and the ability to see issues from multiple perspectives.

- Global attitudes, which means raising global awareness, developing appreciation of other cultures, respect for diversity, a commitment to justice, empathy and tolerance.

- Action, which means democratic participation in the local and global community to solve world problems, i.e. students, should be able to "think globally and act locally" (Cates, 2000, p. 241). 
This study is built on the idea of exploring the above-mentioned dimensions in the context ofUkrainian higher education in general and within the ESP classrooms in particular.

\section{Methodology}

To see the overall picture of the role and place of global issues in the ESP language education in Ukraine, it was crucial to examine each of the dimensions mentioned above. This research focuses on language learners from leading universities of Ukraine - Taras Shevchenko National University of Kyiv and Borys Hrinchenko Kyiv University. The components of research included: (1) analysing ESP textbooks for the occurrence of tasks that address global issues;

(2) defining students' awareness of the global issues, their global attitudes and willingness to act

- in a survey of 120 students from two universities; and (3) identifying the level of development of professional soft and hard skills that may contribute to the development of global competence.

\section{Findings and Discussion}

\section{Source of Knowledge about World Countries and Cultures, and about Global Problems}

In ESP textbooks for the students of Economics, Medicine, Cybernetics, Biology, Philology, and Law, the most frequent global issues addressed are connected with environmental problems, overpopulation, pandemic issues, intercultural communication, and human rights. Yet, the percentage of the tasks in which these issues are mentioned is meagre (see Table one). For the purpose of textbook analysis, tasks touching upon global issues (GI tasks) were divided into two types: the ones that are purely pedagogical and deal with the development of receptive skills, vocabulary and grammar; and the ones that are real-life and touch upon the development of communication skills, critical thinking and awareness, thus sharing the concepts of criticalpedagogy and global education.

Table 1. Analysis of ESP textbooks used in universities of Ukraine

\begin{tabular}{|l|l|l|l|l|l|}
\hline Coursebook title and publisher & $\begin{array}{l}\text { Year } \\
\text { published }\end{array}$ & $\begin{array}{l}\text { Total } \\
\text { number of } \\
\text { exercises } \\
\text { and/or } \\
\text { tasks }\end{array}$ & $\begin{array}{l}\text { Number } \\
\text { of GI tasks }\end{array}$ & $\begin{array}{l}\text { Pedagogic } \\
\text { al tasks, \% }\end{array}$ & $\begin{array}{l}\text { Real-life } \\
\text { tasks, \% }\end{array}$ \\
\hline $\begin{array}{l}\text { Cambridge English for Scientists, } \\
\text { Cambridge University Press }\end{array}$ & 2011 & 140 & 3 & - & 2.1 \\
\hline $\begin{array}{l}\text { Market Leader (Intermediate), 3 } \\
\text { Ed, Pearson-Longman }\end{array}$ & 2012 & 264 & 9 & 0.8 & 2.6 \\
\hline $\begin{array}{l}\text { Business Advantage } \\
\text { (Intermediate), Cambridge } \\
\text { University Press }\end{array}$ & 2103 & 620 & 22 & 0.8 & 2.9 \\
\hline $\begin{array}{l}\text { International Legal English. A } \\
\text { course for classroom or self-study } \\
\text { use, 2 Ed, Cambridge University } \\
\text { Press }\end{array}$ & 2013 & 540 & 10 & 0.9 & 1 \\
\hline
\end{tabular}




\begin{tabular}{|l|l|l|l|l|l|}
\hline $\begin{array}{l}\text { English for Electrical } \\
\text { Engineering, Garnet Publishing }\end{array}$ & 2014 & 288 & 7 & $1.7 \%$ & $0.7 \%$ \\
\hline $\begin{array}{l}\text { Business Partner, 2 Ed, Pearson } \\
\text { Education Limited }\end{array}$ & 2018 & 342 & 10 & $1.7 \%$ & $1.2 \%$ \\
\hline Average: $2.8 \%$ & & & \\
\hline
\end{tabular}

As the result of textbooks analysis, it can be concluded that neither the edition nor the year of publication influenced the number of the GI tasks that make up less than 3\% of all the tasks. Even though, reportedly, overall awareness of the global issues has been rising for the last decade, coursebook and textbook writers do not pay necessary attention to the global competencedevelopment of the intended learners, leaving a great deal of responsibility for subject teachersas well as giving them some room for manoeuvre in the context sphere.

As seen from the above analysis, ESP textbooks for future graduates in Economics and Medicine contain more GI tasks. The reason might lie in deeper global perspective of the major itself as these subject areas are connected with global interaction of the professionals on differentcorresponding levels.

\section{Soft Skills and Global Competence}

Even though globalisation allows free and immediate transfer of information from one corner of the planet to the other one, helping people to develop global competence to become active participants of world events in order to help governments have more impact on critical social issues with fewer resources is quite challenging. Education must surely play a greater role in engaging people in taking care of the planet and tackling global issues we all face. It means engaging people from all the corners of the world and often involves an imperative change in their behaviour. It implies that globalisation and its positive and negative effects cannot be ignored in university classrooms of the $21^{\text {st }}$ century. Bringing global issues into the language classroom is one way of doing this.

As prior research suggests, bringing global issues such as poverty, racism, homophobia, sexism, war conflicts, pandemics among others into the classroom gives students the opportunity of thinking about social topics and being aware of how they affect human beings in different parts of the world (Martínez Lirola, 2015). This is essential to help students become active and global citizens; this involves building their awareness of the social problems of the world and of the differences between various cultures. This also means that students acquire life skills that are vitally important for their career success on the labour market today.

It is necessary to point out that soft skills are quickly becoming the new benchmark for measuring success. As suggested in the study by Harvard Business School, these soft skills account for as much as $85 \%$ of an individual's success, whereas traditional 'hard skills' (academics, corporate job training, IQ, etc.) only account for $15 \%$. Stanford Research Institute shared the same opinion and revealed that soft skills play an essential role in one's success. Atthe edge of core competency and personal traits, soft skills play a vital role in refining one's behaviour. Soft skills are meant to improve student's life skills and employability and they make 
it possible to deal with different situations meticulously and responsibly. With the help of soft skills, students can survive and sustain in the fierce global competitive spirit (Cabau, 2016).

Therefore, skills represent the second aspect of global education that fits harmoniously into foreign language instruction in the ESP context. The very act of learning a foreign language plays an important role in bringing about global issues, because knowing other people's languageand culture opens doors toward better understanding and communication. Other skills that globaleducation and foreign language education share in higher education are those of collaboration, teamwork, mediation and conflict resolution - skills most sought after in private and public corporations today.

Importantly, teaching methods commonly used in ESP classrooms - projects, role-plays,simulations, and collaborative learning - are particularly well-aligned with global education. Projects give students an opportunity to spend an extensive period exploring a particular topicand use their initiative throughout this exploration. Often, projects become a bridge between classroom learning and real life and help students develop and take actions related to a topic in their lives. Role-plays and simulations contribute to the development of global skills because they give students an opportunity to imagine themselves as other people, in different professionaland social roles, and in different situations - this also provides an important link between the classroom and the real world.

Collaborative (or cooperative) learning can involve projects and role-plays and simulations, as they usually are done in groups, but cooperative learning represents a broader range of activities in which students work together (Kagan, 1994). Collaborative learning is primarily based on recognising the indisputable value of student-to-student interaction. Through successful interaction in the classroom, students can develop the skills and attitudes necessary forsuccessful interaction in other spheres and can develop a belief in the power of cooperation (Jacobs, 1998). This is reinforced by a fundamental concept in collaborative learning - that of positive interdependence - the feeling among group members that they sink or swim together, that what helps one member helps all and that what hurts one hurts all (Johnson \& Johnson, 1994). This positive interdependence in real life would indeed contribute to making our world a better, more humane place.

Thus, since ESP classroom is a place where soft skills are being developed through the pedagogical perspective anyway, an extra focus on global issues and finding collaborativesolutions to those would benefit our aim of educating global citizens.

\section{Students' Awareness of Global Issues, their Global Attitudes and Willingness to Act}

Results of the survey of 120 first and second year ESP students on their awareness of global issues and on their level of development of global competence demonstrate that Ukrainian future professionals are not ready to become global citizens because of lack of awareness, intrinsic motivation to contribute to international development and insufficient sources of appropriate knowledge introduced in school. 
It is perhaps not surprising that our findings suggest that almost three-fourths of those who have not had a chance to learn about global issues in school or on their own think that it is pointless for them to act on global issues. (72\%) (see Figure one). Amongst those who learnt about global issues either at school or by themselves (these are only $15 \%$ of respondents), the proportion of people who feel powerless goes down significantly, with only $10 \%$ of the respondents agreeing that it is pointless to act.
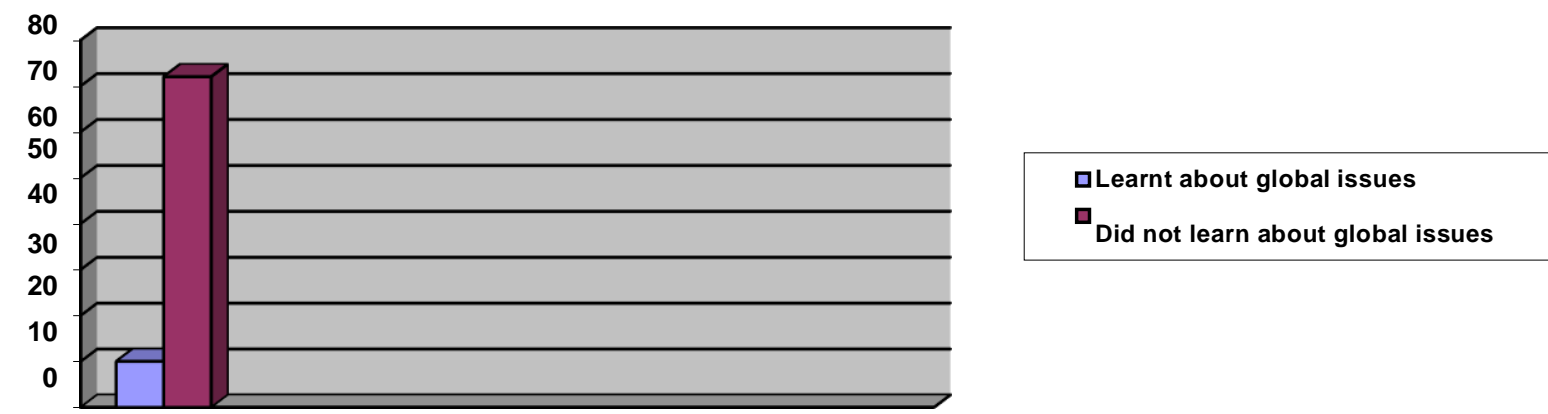

Figure 1. Proportion of respondents who feel it is pointless for them to act on global issues

Learning about global issues can make a substantial contribution to stepping up international development and mutual national support. In our survey, we decided to concentrate on the issues of poverty and the role of international aid and mutual national assistance as this idea is not strange to many Ukrainians as the country is itself a recipient of various international instruments and also engages in mutual national aid mechanisms. According to responses,amongst those who learnt about global issues, $31 \%$ agree that there are more important issues to tackle than poverty in developing countries, and $45 \%$ of them support the idea of providing help to overcome the problem. However, amongst those who did not learn about global issues, $61 \%$ agree and only $7 \%$ support the idea of mutual national assistance (see Figure two).

Thus, students who care about global issues are more aware of the necessity to donate to international development (e.g. to NGOs). They are also more likely to understand how they can contribute to global development through their own daily actions (e.g. by purchasing fair trade products).

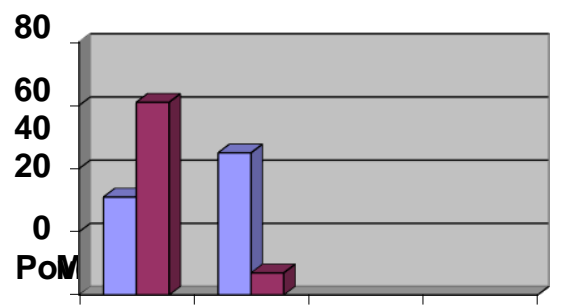

\section{口Learnt about global issues \\ ${ }^{\square}$ Did not learn about global issues}

Figure 2. Proportion of respondents who support the idea of mutual national assistance in globalissues 
Global learning is also vital if we are to counter misconceptions about racial and religious differences by encouraging respect and welcoming inclusion and diversity. These are crucial for making this world a more harmonious place. Our findings suggest that amongst those who have not experienced global learning in school, a quarter of the respondents $(26 \%)$ are not comfortablewith there being so many different races and religions living in Ukraine today or studying at theiruniversity. Amongst those who have learnt about at least one global issue, only $6 \%$ express this discomfort (see Figure three).

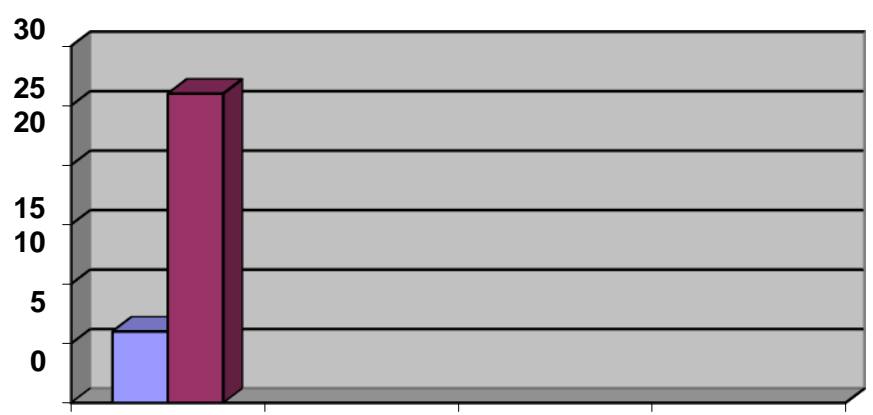

口Learnt about global issues

DDid not learn about global issues

Figure 3. Proportion of respondents who are not comfortable with variety of races and religionsaround them

This suggests that promoting diversity and inclusion through encouraging a global perspective in universities is an important and effective mechanism for developing a moreprogressive and tolerant society.

By ensuring that all educational establishments offer opportunities to learn about global issueswe will be able to dramatically decrease the number of those unaware or uninterested in theworld around them. In contrast, if our universities ignore the need for global learning, this may turn the situation for the worse, as this will only increase the number of those uninterested in taking positive social action.

\section{Action}

Past research studies from DFID indicate that around 20\% of the UK population are "disengaged, inwardlooking and uninterested in or unsympathetic to the world around them". These are the people who are not interested in getting involved in any form of positive social action, such as recycling, volunteering or campaigning on global issues. However, amongst those who have learnt about climate change, poverty or world politics and trade at school, this figure roughly halves (9\%, 12\% and 12\% respectively). Even more strikingly, amongst those who have not had an opportunity to learn about any global issues at school, over a third (34\%), are entirely disengaged (DFID, 2008). Interestingly, according to UN-funded research on volunteering in Ukraine, Ukrainians recognize an essential role of volunteering in societal change, $85 \%$ of respondents believe that volunteering helps peacebuilding and $81 \%$ acknowledge that volunteering should be an indispensable component of civil society. Moreover, $23 \%$ of Ukrainians report that they have taken part in volunteering efforts over the last year (Nationwide Research, 2015). 
In Ukraine, considerable progress has been made to incorporate global issues throughout school curricular. Such global problems as environmental pollution and the role of humans in it, discrimination, hunger, poverty, etc. have been included in secondary educational establishmentsas part of the school reform. This has contributed to raising the awareness of students' social responsibility. All of the above has a direct impact on students being proactive in terms of global awareness and democratic participation in the local and global community to solve world problems. Our findings show that only 5\% of respondents are not interested in engagement in positive social actions. Those who have experienced learning about global issues are ready to participate in volunteering projects or actions, have already participated in local volunteer events or are planning to become members of various NGOs trying to tackle global issues. We may see that only $1 \%$ of respondents are not interested in or are just indifferent to making a positive contribution through social action (see Figure four).

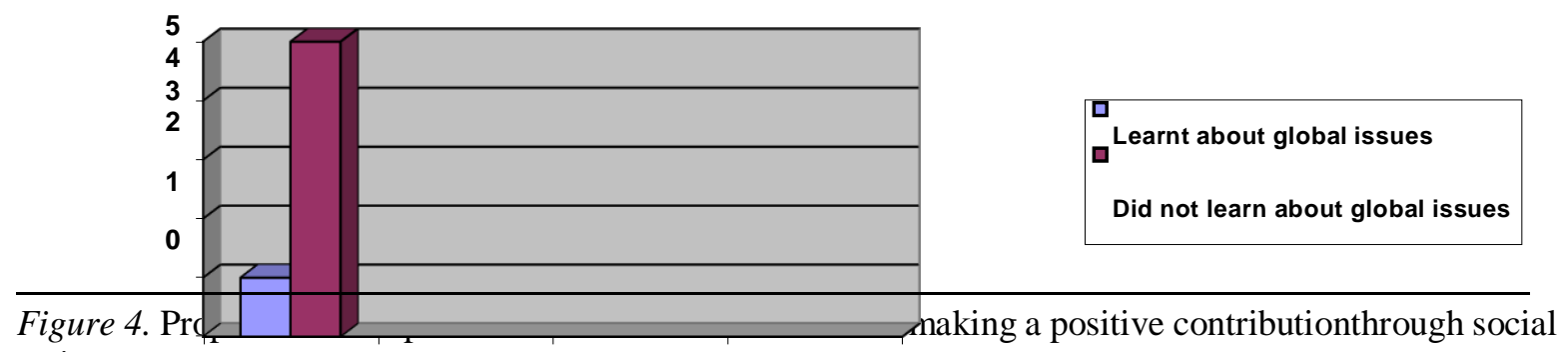
action

Finally, there is a significantly large proportion of students who support the idea that all members of society should have the opportunity to learn about global issues either in schools or in universities. Almost nine in ten (89\%) of the respondents believe that global learning in university is crucial if these issues are to be tackled in future (see Figure five). These findings indicate that there is a strong mandate for universities and other stakeholders to make global learning in higher education a priority. This leads us to the suggestion that integration of global issues to the professional soft and hard skills development in the ESP context will raise students' motivation to learn a target language, contribute greatly into the education of future global citizens and improve the requirements profile of a future professional.

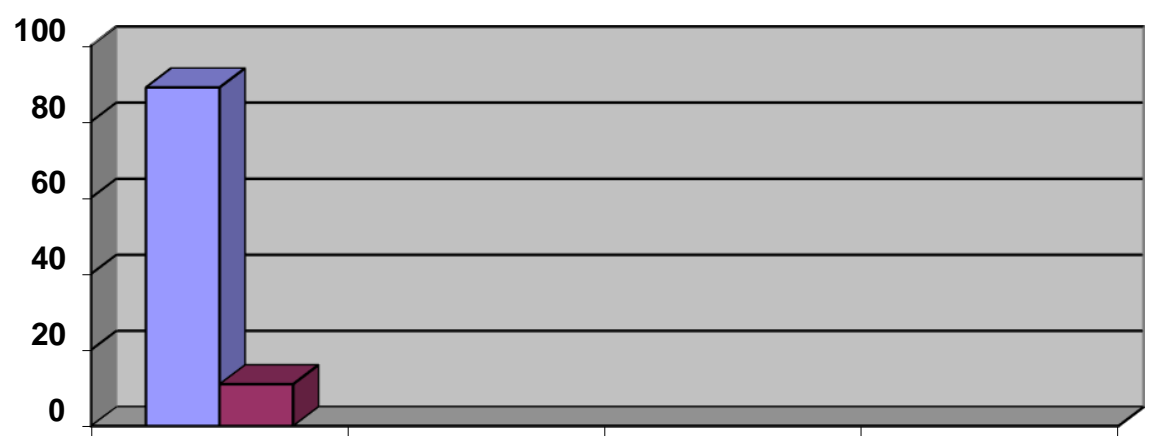

Figure 5. Proportion of respondents who believe that global learning is crucial in tackling globalproblems 
Summing up all the challenges teachers and learners face while introducing global issues into the ESP classroom - lack of awareness of the importance of global issues; topic-based content as opposed to problembased; learning outcomes limited to language and skills; insufficient educational policy support; lack of teacher support (professional development); existing materials not providing for a meaningful variety of real-life tasks involving globalissues; predominantly mono-cultural classes in Ukraine: 'cultural awareness' limited mostly to UK and US stereotypical notions of cultures - it is possible to conclude that Ukrainian graduates might be less competitive on the world labour market with their global competence beingunderdeveloped. It is also necessary to stress the importance of teaching global contexts in foreign language classrooms with particular attention to:

a) variety of multinational, multilingual, and multicultural contents: authentic materials, structured documents etc.;

b) development of appropriate methodologies for teaching foreign languages in the spirit of global education;

c) improved teacher training programmes with a specific focus on teaching culture and global education (global pedagogy, curriculum development, methodology, etc.);

d) development of coursebooks and learning resources for the purpose of global education and international understanding;

e) stepping up intercultural research with thorough analysis of different forms of cultural contact and cultural exchanges.

\section{Conclusion}

In a modern academic environment, educators face a great number of challenges in teaching ESP. Labour market seeks professionals ready to think globally, to operate on an international arena being aware of the global problems, sympathetic and tolerant. This paper concentrated on the analysis of the main challenges in ESP teaching and learning. Taking into consideration ESP context, modern requirements of the labour market and the level of students and teachers'awareness, the ways of integrating global issues into the process of development of professional skills, soft skills, and global competence in the ESP classroom were suggested. It was suggested in the paper that the fusion of professional skills, soft skills, and global competence is likely to improve the employment profile of a future professional and to make a positive impact of global education approach within ESP classes on learning process and on quality of higher education in general.

\section{Recommendations}

Therefore, in order to educate global citizens and to meet the requirements of contemporarylabour market, ESP teachers need to:

- be aware of their responsibility in furthering international understanding through their teaching; - make efforts to increase the effectiveness of teaching foreign languages with a view of enhancing mutual understanding, respect, peaceful co-existence and co-operation among nations;

- exploit the possibilities of extra-curricular activities for the development of international contacts and co-operation, such as correspondence, exchange of books and relevant print and audio-visual material, virtual cooperation, exchange programmes, visits, tours, excursions etc. 
- stimulate co-operation by language teaching approaches responsive to students' initiatives, interests and needs, as education for international co-operation must start with co-operation between students and teacher in the language learning task, classroom.

Actions to take include raising educators' and learners' awareness of the importance of globalissues; complementing core ESP curriculum with targeted content addressing global issues; developing policy guidelines for inclusion and promotion of global education at all levels;designing additional materials dealing with global issues to complement the gaps in the existing ones; involving learners and other stakeholders to the development of materials; encouraging broader discussion of the importance of global issues in the national media.

\section{About Authors:}

Yana Diachkova $\mathrm{PhD}$, (in Education), assistant professor in the Department of Foreign Languages of the Faculty of Economics of Taras Shevchenko National University of Kyiv, Ukraine. Her research interests touch upon contemporary higher education trends, methodology of teaching English for Specific Purposes and the use of modern technologies and instruments ineducation. ORCID code: https://orcid.org/0000-0003-3145-6695

Lilia Sazhko PhD, (in Education), professor in the Department of German Philology of theInstitute of Philology of Borys Hrinchenco Kyiv University, Ukraine.

The research interests cover methodology of teaching foreign languages and globalization of higher education. ORCID code: https://orcid.org/0000-0002-1565-6091

Liudmyla ShevchenkoPhD, (in Philology), associate professor in the Department of Foreign Languages of the Faculty of Economics of Taras Shevchenko National University of Kyiv, Ukraine. Her research interests embrace assessment procedures in higher education, the ways of developing cultural competence in teaching English for Specific Purposes.

ORCID code: https://orcid.org/0000-0002-4543-3876

Anastasiia Syzenko PhD. (in Philology), associate professor in the Department of ForeignLanguages of the Faculty of Economics of Taras Shevchenko National University of Kyiv, Ukraine. Her research interests include internationalisation of higher education, the use of learning technologies and new developments in teaching English for Specific Purposes.

ORCID code: https://orcid.org/0000-0001-8443-7813

\section{References}

Andrusiak, I., \& Onischuk, I. (2018). ESP Teaching in the Context of Ukrainian HigherEducation: Challenges and Solutions.

APN (2017). The Uncomfortable Truth: Racism, Injustice, and Poverty in New Jersey. Retrieved from http://www.antipovertynetwork.org/resources/Documents/The\%20Uncom fortable\%20Truth\%20Final\%20-\%20web.pdf

Byram, M. (2020). Teaching and Assessing Intercultural Communicative Competence: Revisited. Multilingual Matters 
Cabau, B. (2016). Language and Content Courses: A Plea for Synergy in Academic Programmes. Journal of European Languages and Literatures, (1). Available at http://interface.org.tw/index.php/if/article/view/25/187

Cates, K. (2000). Entry for 'Global Education', In M. Byram, (Ed.), Routledge Encyclopaedia ofLanguage Teaching and Learning (pp. 241-243). London: Routledge

Council of Europe. (2018). Reference Framework of Competences for Democratic Culture. Context, Concepts and Model (Vol.1). Council of Europe.

DFID (2008). Communication Matters. Retrieved from https://assets.publishing.service.gov.uk/media/57a08b3c40f0b64974000a58/DFID resear ch_final_161008.pdf

Global Situation Report (2020). A United Voice for Global Change. Retrieved from https://www.interaction.org/wp-content/uploads/2020/01/Global-SituationReport-1.pdf

Hogg, M., \& Shah, H. (2010). The impact of global learning on public attitudes and behaviourstowards international development and sustainability. DEA, London, CAN Mezzanine. Retrieved from http://www.ceipaz.org/images/contenido/DEAImpact_of_global_learning_research.pdf

Jacobs, G. M. (1998). Cooperative learning or just grouping students: The difference makes a difference. In W.A. Renandya, \& G.M. Jacobs, (eds.), Learners and language learning (pp. 172-193). Singapore: SEAMEO Regional Language Centre.

Johnson, D. W., \& Johnson, R. T. (1994). Learning together and alone. Cooperative, Competitive, and Individualistic Learning ( $4^{\text {th }} \mathrm{ed}$.). Needham Heights, MA: Allyn and Bacon.

Kagan, S. (1994). Cooperative learning. San Clemente, CA: Kagan Cooperative Learning. Retrieved from https://www.scirp.org/(S(351jmbntvnsjt1aadkposzje))/reference/ReferencesPapers. aspx?Ref erenceID $=1412298$

Karapetian, A. O. (2020). Creating ESP-Based Language Learning Environment to Foster Critical Thinking Capabilities in Students' Papers. European Journal of EducationalResearch, 9(2), (pp. 717-728).

Kennedy, K. (2007). Student constructions of active citizenship: What does participation mean tostudents? British Journal of Educational Studies, 55(3), 304-324.

Martínez Lirola, M. (2015). Introducing global issues in a language classroom: getting to know other cultures through the analysis of multimodal texts from NGOs. International Journalof Education for Piece and Development, 3(1), 27-36. Retrieved from https://rua.ua.es/dspace/bitstream/10045/48806/1/2015_MartinezLirola_IJEPD.pdf

Volunteering in Ukraine. Nationwide Research Publication. - Kyiv, 2015. - 32 p. Retrievedfrom: http://www.un.org.ua/images/volunteer.pdf

Yakovchuk, N. (2004). Global Issues and Global Values in Foreign Language. University of Warwick, the UK. Retrieved from https://wrap.warwick.ac.uk/3245/1/WRAP_Yakovchuk_yakovolume8.pdf 